\title{
ANALISIS SPASIAL DINAMIKA KONVERSI LAHAN DI KABUPATEN GOWA, SULAWESI SELATAN
}

\author{
Spatial Analysis of Land Conversion Dynamics in Gowa Regency, \\ South Sulawesi
}

Munawir $^{1}$, Baba Barus², Untung Sudadi²

Diterima: 2 November 2017 Disetujui: 30 November 2017

\begin{abstract}
Abstrak: Intensitas pembangunan di Kota Makassar serta integrasi wilayah ke dalam KSN Mamminasata menghasilkan proses transformasi fisik-spasial dan mengakibatkan tingginya konversi lahan di Kabupaten Gowa. Penelitian ini bertujuan untuk (1) Menganalisis konversi lahan, dan faktor penentunya di Kabupaten Gowa dalam lima titik tahun (1998, 2003, 2007, 2011, 2016), serta (2) Menganalisis dinamika konversi lahan tersebut. Analisis yang digunakan meliputi (1) analisis penggunaan lahan dan konversi lahan, (2) analisis faktor penentu konversi lahan, dan (3) analisis dinamika konversi lahan. Hasil penelitian menunjukkan bahwa total konversi lahan di Kabupaten Gowa selama periode tahun 1998-2016 sebesar 3.23\%. Penggunaan lahan dengan peningkatan luasan tertinggi yaitu lahan terbangun, sedangkan penurunan luasan tertinggi yaitu sawah dan ladang/tegalan. Faktor yang mempengaruhi konversi lahan sawah menjadi lahan terbangun meliputi kepadatan penduduk, jarak dari ibukota kabupaten, jarak dari ibukota kecamatan, jarak dari pasar, pola ruang Kabupaten Gowa, dan Integrasi ke dalam KSN Mamminasata, sedangkan konversi ladang/tegalan dipengaruhi faktor lereng, kepadatan penduduk, jarak dari jalan arteri, jarak dari kota kabupaten, jarak dari objek wisata, pola ruang Kabupaten Gowa, dan Integrasi ke dalam KSN Mamminasata. Penggunaan lahan paling dinamis berkembang yaitu lahan terbangun dan semak belukar, sementara intensitas konversi lahan tertinggi yaitu transformasi penggunaan lahan sawah, ladang/tegalan, semak belukar menjadi lahan terbangun.
\end{abstract}

\section{Kata Kunci : Dinamika konversi lahan, Kabupaten Gowa}

Abstract: Intensity of development in Makassar City and integration to KSN Mamminasata cause physical-spatial transformation process and high land conversion in Gowa Regency. The objectives of this research are (1) to know land conversion and driving factors in Gowa Regency in five periods (1998, 2003, 2007, 2011, 2016), and (2) to know the dynamics conversion of land use. The results showed that the total conversion of land use in Gowa Regency during the period of 1998-2016 amounted to $3.23 \%$. Highest increase of land is built up, while highest decrease is paddy fields, and fields. Driving factor influencing conversion of paddy field into built-up is population density, distance from district capital, distance from sub-district capital, distance from market, policy of spatial pattern of Gowa regency, and integration into KSN Mamminasata, while the driving factor is influencing conversion of fields to built-up by slope, population density, distance from the arterial road, distance from district capital, distance from the tourist object, policy of spatial pattern of Gowa regency, and integration into KSN Mamminasata. Land use dynamic developing is a built-up and shrubs, while highest intensity of conversion is the transformation of paddy fields, fields, and shrubs to built-up land.

Keywords: Dynamic Land Conversion, Gowa Regency

\footnotetext{
${ }^{1}$ Program Studi Ilmu Perencanaan Wilayah, Institut Pertanian Bogor

${ }^{2}$ Fakultas Pertanian, Institut Pertanian Bogor
} 


\section{PENDAHULUAN}

Proses pembangunan di Kota Makassar yang berlangsung dengan intensitas tinggi memperlihatkan perkembangan fisik kota yang mulai keluar ke wilayah pinggirannya. Laju pembangunannya nyaris tidak dapat dikendalikan, sementara kuantitas lahan yang bisa dimanfaatkan relatif tidak bertambah. Kondisi ini, mengisyaratkan terjadinya pergeseran aktivitas pembangunan dari pusat kota ke wilayah lain di sekitarnya. Implikasi dari pengaruh tersebut ditandai dengan proyek-proyek pengembangan perumahan yang mulai merembet ke wilayah pinggiran Kota Makassar, termasuk ke wilayah Kabupaten Gowa. Dampak nyata yang tidak dapat dihindari yaitu perubahan fungsi penggunaan lahan wilayah yang semula didominasi areal pertanian menjadi bentuk pemanfaatan lahan perkotaan.

Kitchin and Thrift (2009) mengemukakan bahwa proses perembetan area perkotaan jika terjadi secara berkelanjutan akan menghasilkan kenampakan fisik perkotaan baru yang terjadi secara tidak terencana dan tidak terkontrol. Di Kota Makassar, implikasi ini ditandai dengan perluasan kegiatan ekonomi strategis dan fungsi sosial lainnya dengan proses transformasi yang terjadi terus menerus ke arah pinggiran kota (Surya, 2015). Polarisasi fungsi-fungsi aktivitas sosial ekonomi tersebut diikuti dengan pembangunan prasarana jalan utama yang menghubungkan antara Kota Makassar dan Kabupaten Gowa (Radinal, 2017).

Pertumbuhan penduduk di suatu wilayah akan berbanding lurus dengan besarnya beban wilayah tersebut terutama dalam menyediakan ruang untuk keperluan penduduknya (Warlina, 2011). Badan Pusat Statistik (BPS) Kabupaten Gowa mencatat bahwa kurun waktu tahun 2007-2014 jumlah penduduk Kabupaten Gowa terus mengalami peningkatan dengan laju pertumbuhan penduduk sekitar 2,63\% per tahun. Tekanan populasi di Kabupaten Gowa diperkirakan akan semakin meningkat secara signifikan pada masa yang akan datang. Kepadatan penduduk yang tinggi dapat berasosiasi dengan tingginya intensitas aktivitas ekonomi melalui aglomerasi ekonomi (Liu et al, 2011). Sebagai respon dari hal tersebut, 11 (sebelas) kecamatan dari 18 (delapan belas) kecamatan yang terdapat di Kabupaten Gowa diintegrasikan ke dalam Kawasan Strategis Nasional (KSN) Mamminasata, yang dibentuk dengan tujuan sebagai penggerak utama pembangunan di Kawasan Timur Indonesia (Perpres No.55/2011).

Konsekuensi logis dari terintegrasinya sebagian wilayah Kabupaten Gowa ke dalam KSN Mamminasata, yaitu terjadinya proses transformasi fisik-spasial karena meningkatnya pembangunan. Nilai lahan (land rent) untuk aktivitas pertanian menjadi tergantikan dengan aktivitas lain seperti industri, perumahan, dan jasa yang dapat memberikan rent lebih tinggi. Akibatnya, lahan pertanian menjadi rentan terkonversi. Hasil penelitian Ashari (2015) di KSN Mamminasata menunjukkan bahwa selama periode tahun 1995-2011 terjadi peningkatan lahan terbangun yang massif disertai penurunan luasan lahan sawah. Sebagian besar perubahan tersebut berada di sekitar Kota Makassar dan Kabupaten Gowa. Kondisi ini, jika tidak diantisipasi maka perkembangan kota akan terus menerus mengancam eksistensi lahan pertanian di wilayah tersebut. Mayoritas dari wilayah Kabupaten Gowa yang terintegrasi ke dalam KSN Mamminasata adalah areal persawahan beririgasi teknis.

Kuantitas lahan relatif tetap, sedangkan permintaan akan ketersediaan lahan semakin meningkat untuk berbagai keperluan. Kebutuhan untuk menghadirkan maupun menambah luasan dari jenis penggunaan lahan tertentu menyebabkan lahan-lahan di sekitarnya menjadi lebih dinamis terkonversi. Dinamika konversi mencirikan tingkat kemudahan terjadinya konversi dari suatu jenis penggunaan lahan berdasarkan perilaku konversi lahan yang diamati dari waktu ke waktu (Liang et al, 2011). Dinamika konversi penggunaan lahan 
terutama dimaksudkan untuk memantau perbedaan manfaat yang dihasilkan oleh jumlah input/output dari suatu luas lahan pada durasi waktu tertentu (Gu et al, 2016), juga untuk dapat mengetahui kompleksitas interaksi antara sistem alam dan sosial-ekonomi pada skala spasial-temporal yang berbeda (Veldkamp and Lambin, 2001).

Pengetahuan tentang dinamika konversi lahan dapat memberikan dasar yang ilmiah untuk digunakan dalam membuat keputusan yang rasional terkait pemanfaatan sumber daya lahan, penentuan model penggunaan lahan optimal, agar tercapainya pembangunan yang berkelanjutan (Zhang, 2014). Penelitian ini bertujuan untuk (1) Mengetahui konversi lahan yang terjadi, dan faktor penentunya di Kabupaten Gowa dalam lima titik tahun (1998, 2003, 2007, 2011 dan 2016), serta (2) Menganalisis dinamika konversi penggunaan lahan tersebut.

\section{METODE}

Penelitian dilakukan pada bulan Agustus 2016 - Juni 2017 di Kabupaten Gowa. Secara geografis lokasi penelitian terletak pada $5^{\circ} 33^{\prime}$ 6" $5^{\circ} 34^{\prime} 7^{\prime \prime}$ LS dan $12^{\circ} 38^{\prime} 6^{\prime \prime}$ $12^{\circ} 33^{\prime} 6^{\prime \prime}$ BT. Secara administratif Kabupaten Gowa berbatasan dengan Kota Makassar dan Kabupaten Maros di sebelah Barat, Kabupaten Sinjai dan Kabupaten Bantaeng di sebelah Timur, Kabupaten Maros di sebelah Utara, Kabupaten Takalar di sebelah selatan. Peta lokasi penelitian ditunjukkan pada Gambar 1.

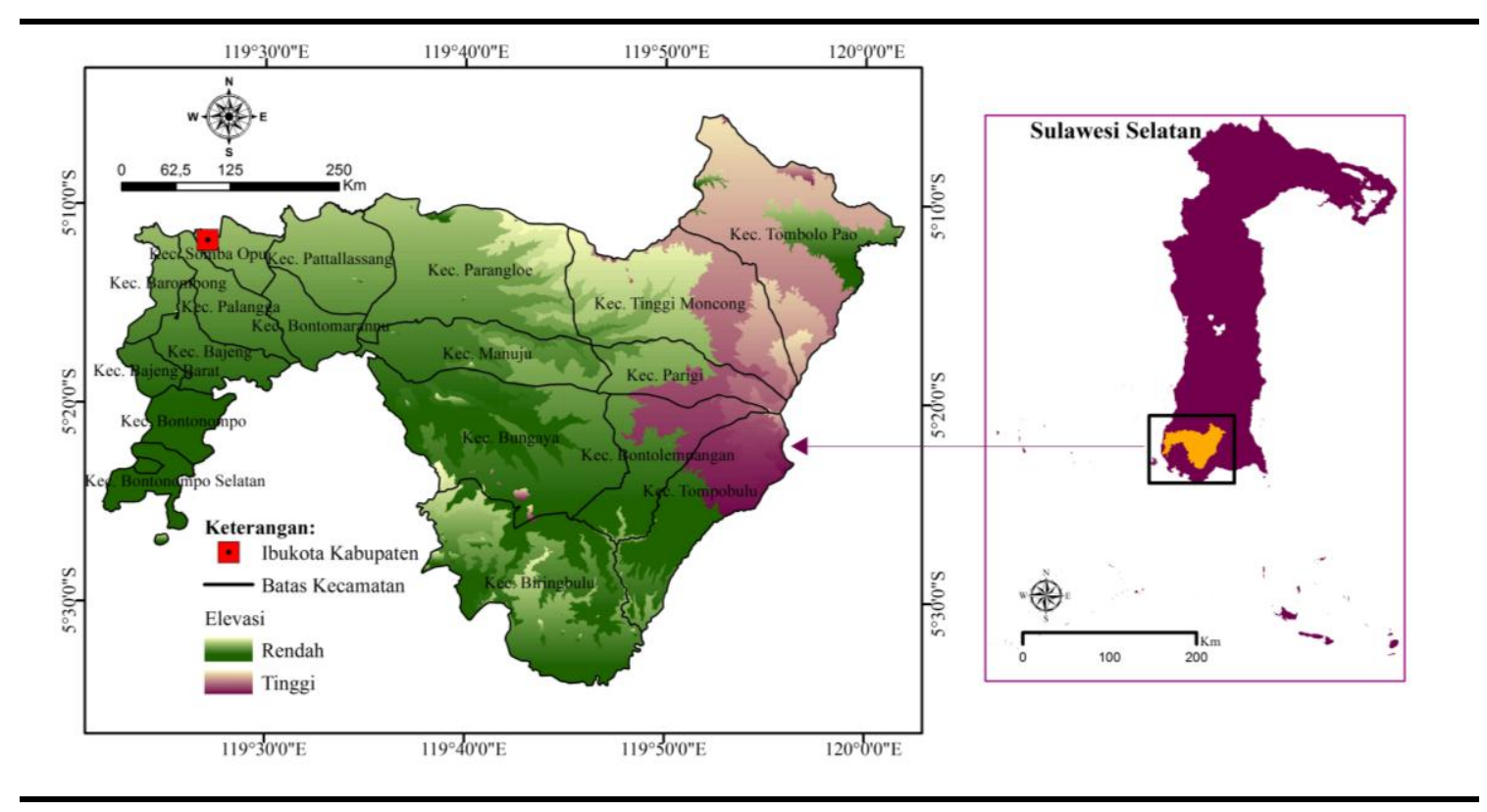

Gambar 1. Peta Lokasi Penelitian

\section{Jenis Data dan Metode Pengumpulan Data}

Jenis data yang digunakan adalah data primer dan data sekunder. Data primer yang digunakan yaitu data survey lapangan yang digunakan untuk menguji ketelitian klasifikasi penggunaan lahan dengan kondisi sebenarnya dilapangan. Data sekunder meliputi citra satelit Landsat TM 5 tahun 1998, dan tahun 2002, Landsat ETM+ 7 tahun 2007, dan tahun 2011, dan Landsat 8 tahun 2016, peta lereng, peta jaringan jalan, peta pusat ekonomi, peta lokasi pariwisata, peta pola ruang Kabupaten Gowa, Peta pola ruang KSN Mamminasata, data atribut, laporan penelitian, dan perundang-undangan. Data sekunder diperoleh dari 
berbagai sumber baik instansi pemerintah, literatur maupun situs-situs penyedia data dan informasi sumber tertulis yang telah ada berkaitan dengan materi yang akan diteliti.

\section{Metode Analisis Data}

\section{Analisis Penggunaan dan Konversi Lahan}

Klasifikasi penggunaan lahan di Kabupaten Gowa dihasilkan melalui data penginderaan jauh berupa citra satelit Landsat. Citra penginderaan jauh sangat bermanfaat dalam mengekstrak informasi spasial, terutama yang membutuhkan liputan yang luas dan dalam kurun waktu yang cukup panjang (Barus et al, 2012). Metode yang digunakan yaitu interpretasi visual (on screen digitazion). Interpretasi citra merupakan perbuatan mengkaji citra dengan maksud untuk mengidentifikasi obyek dan memberi makna pada obyek yang terdapat pada citra tersebut. Unsur-unsur yang digunakan sebagai dasar analisis meliputi: ukuran, rona (tone), warna, tekstur, pola, bentuk, bayangan, asosiasi dan situs (Lillesand and Keifer, 1997). Hasil dari interpretasi tersebut adalah peta penggunaan lahan Kabupaten Gowa tahun 1998, 2002, 2007, 2011 dan 2016. Untuk mendapatkan gambaran konversi penggunaan lahan, peta penggunaan lahan tersebut dianalisis secara spasial dan disajikan dalam bentuk matriks transisi konversi lahan.

\section{Analisis Faktor-Faktor Penentu Konversi Lahan}

Konversi penggunaan lahan yang dianalisis dalam penelitian ini adalah konversi penggunaan lahan sawah dan ladang/tegalan menjadi lahan terbangun pada periode tahun 1998-2016. Analisis statisik yang digunakan berupa analisis regresi logistik biner. Penggunaan model ini bertujuan untuk mengetahui pengaruh dari seperangkat variabel prediktor terhadap variabel yang dipengaruhi (Fitsmaurice and Laird, 2015). Karakteristik dari model ini yaitu bahwa variabel dependen terbatas pada variabel diskrit, probabilitas perubahan penggunaan lahan dinyatakan sebagai probabilitas kejadian (Peng et al, 2017). Model regresi logistik mengisyaratkan data yang bersifat dikotomi, oleh karena itu konversi penggunaan lahan dinyatakan ke dalam bilangan 0 dan 1 . Nilai 0 mewakili tidak terjadi konversi sawah dan ladang/tegalan menjadi lahan terbangun, dan nilai 1 mewakili terjadinya konversi sawah dan ladang/tegalan menjadi lahan terbangun.

Metode yang digunakan yaitu forward stepwise. Prinsip dasar analisis ini adalah mengurangi banyaknya variabel satu demi satu dengan cara seleksi ke depan dan eliminasi ke belakang sampai diperoleh tingkat kecocokan yang paling optimal (Thomas and Peethamparan, 2017). Umumnya, konversi penggunaan lahan diperkirakan akan terjadi di lokasi yang memiliki preferensi tertinggi untuk jenis penggunaan lahan lain pada saat tertentu (Sun et al, 2016). Pemilihan variabel yang dimasukkan berdasarkan variabel bebas yang memiliki korelasi lebih besar dengan variabel terikat. Metode regresi logistik biner menggunakan persamaan sebagai herikut:

$$
\log \quad[=\beta]+\beta_{1} \mathrm{X}_{1,1}+\beta_{2} \mathrm{X}_{2,1} \ldots \beta \mathrm{nXn}
$$

Dimana $\boldsymbol{P}_{1}$ adalah nilai peluang peubah tetap ke-i; $\boldsymbol{\beta}$ o adalah konstanta; $\boldsymbol{\beta}_{1-}$ n'merupakan koefisien peubah bebas ke-1 sampai n; $\mathbf{X}_{1 \text {-n } 1}$ Peubah bebas ke 1 sampai n, pada peubah tetap ke 1; $\mathbf{n}$ Jumlah peubah; dan X1, X2, X3 . . . X13 adalah variabel yang digunakan meliputi jenis kemiringan lereng, kepadatan penduduk, jarak dari jalan arteri, jarak dari jalan kolektor, jarak dari ibukota kabupaten, jarak dari ibukota kecamatan, jarak dari kampus, jarak dari objek wisata, jarak dari pasar, kebijakan pola ruang, dan integrasi kawasan ke dalam KSN Mamminsata (Gambar 2 ). 


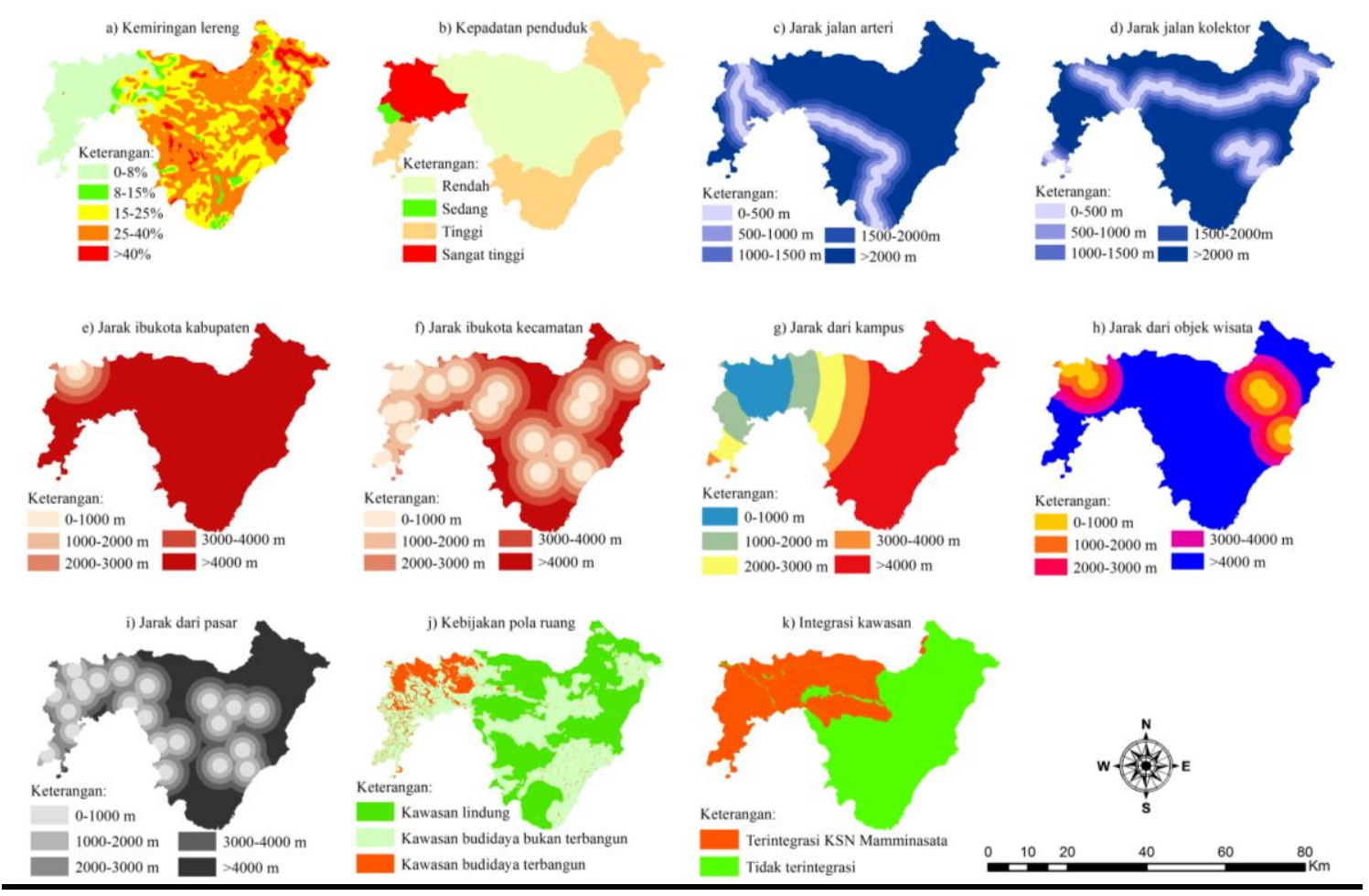

Gambar 2. Faktor-faktor penentu konversi lahan yang digunakan dalam penelitian

\section{Analisis Dinamika Konversi Lahan}

\section{Indeks Dinamika Konversi Penggunaan Lahan}

Konversi lahan yang terjadi kemudian diboboti menggunakan perhitungan indeks dinamika konversi penggunaan lahan (Ki) untuk mengetahui tingkat dinamikanya. Indeks dinamika penggunaan lahan dapat secara kuantitatif menggambarkan perbandingan kecepatan konversi penggunaan lahan di suatau wilayah dan memprediksi tren penggunaan lahan di masa depan, yang secara kuantitaif dihitung dengan persamaan (Luo et al, 2014) :

$$
\mathrm{Ki}=\left[\left(\mathrm{u}_{\mathrm{b}}-\mathrm{u}_{\mathrm{a}}\right) / \mathrm{u}_{\mathrm{a}}\right] \times \mathrm{T}^{-1} \times 100 \%
$$

Dimana $\mathrm{K}$ adalah indeks dinamika konversi untuk setiap jenis penggunaan lahan, Ua dan $\mathrm{Ub}$ adalah luas penggunaan lahan pada awal dan akhir periode, dan $\mathrm{T}$ adalah periode penelitian. Jika nilai Ki $>0$, berarti bahwa suatu jenis penggunaan lahan terus mengalami perkembangan di wilayah tersebut, sebaliknya jika nilai $\mathrm{Ki}<0$ berarti penggunaan lahan tersebut mengalami penurunan luasan (Wang et al, 2010).

\section{Indeks Intensitas Konversi Penggunaan Lahan}

Indeks intensitas dinamika penggunaan lahan dapat digunakan untuk menggambarkan tingkat konversi dari semua jenis penggunaan pada periode waktu tertentu di suatu wilayah, yang dinyatakan dengan persamaan (Wang and Bao, 1999; Zhang, 2014), sebagai berikut: 
$D_{i}=\sum_{i=1}^{N} s_{b i^{-}}-s_{a i^{-}} / 2 \sum_{i=1}^{N} s_{a i^{i}} \times T^{-1} \mid \times 100 \%$

Di mana $D_{i}$ adalah indeks intensitas konversi penggunaan lahan jenis i pada periode T; $\boldsymbol{N}$ adalah jumlah jenis penggunaan lahan; $\boldsymbol{S}_{a i}, \boldsymbol{S}_{b i}$ adalah luas penggunaan lahan yang menggunakan jenis i pada awal dan akhir periode pengamatan; dan $\boldsymbol{T}$ adalah periode penelitian. Penggunaan model ini dapat dipahami sebagai representasi intensitas suatu penggunaan lahan dalam periode waktu tertentu.

\section{HASIL DAN PEMBAHASAN}

\section{Interpretasi Penggunaan Lahan}

Klasifikasi kelas penggunaan lahan di Kabupaten Gowa meliputi: hutan, kebun campuran, lahan terbangun, sawah, ladang/tegalan, tubuh air, lahan terbuka dan semak belukar. Peta penggunaan lahan disajikan pada Gambar 3. Secara umum penggunaan lahan di kabupaten Gowa didominasi oleh ladang/tegalan (35\%), hutan (32\%), dan sawah (19\%). Penggunaan lahan ladang/tegalan ditemukan secara parsial di seluruh wilayah, namun utamanya terkonsentrasi di bagian selatan Kabupaten Gowa, sedangkan penggunaan lahan hutan ditemukan di bagian utara dan bagian timur Kabupaten Gowa. Adapun penggunaan lahan sawah sebagian besar mengelompok di bagian barat yaitu pada daerah yang relatif datar, serta ditemukan juga sebagian kecil di wilayah timur dan selatan Kabupaten Gowa. Selengkapnya disajikan pada Tabel 1.

\section{Konversi Penggunaan Lahan}

Luas total konversi penggunaan lahan selama periode 1998-2016 sebesar 5.840 ha atau $3.23 \%$ dari luas wilayah Kabupaten Gowa (Tabel 2). Berdasarkan konversi lahan yang terjadi menunjukkan bahwa penggunaan lahan kebun campuran, lahan terbangun, lahan terbuka, dan semak belukar yang mengalami peningkatan luasan. Lahan terbangun secara massif mengalami peningkatan luasan pada periode tersebut yaitu sebesar 2.569 ha atau $44 \%$, disusul semak belukar sebesar 328 ha atau 6\%, dari jumlah keseluruhan konversi yang terjadi. Peningkatan-peningkatan tersebut diiringi dengan penurunan luasan pada penggunaan lahan lainnya. Penggunaan lahan sawah menurun secara drastis pada periode tersebut yaitu sebesar 1.345 ha atau 23\%, diikuti penggunaan lahan hutan sebesar 974 ha atau $17 \%$, dan penggunaan lahan ladang/tegalan sebesar 610 ha atau $10 \%$. Tren konversi penggunaan lahan di Kabupaten Gowa disajikan secara spasial dan grafik seperti pada Gambar 4 dan Gambar 5.

Tabel 1 . Luas penggunaan lahan di Kabupaten Gowa pada berbagai periode pengamatan

\begin{tabular}{|c|c|c|c|c|c|c|}
\hline \multirow{2}{*}{ No } & \multirow{2}{*}{$\begin{array}{c}\text { Penggunaan } \\
\text { lahan }\end{array}$} & Tahun 1998 & Tahun 2002 & Tahun 2007 & Tahun 2011 & Tahun 2016 \\
\hline & & ha & ha & ha & ha & ha \\
\hline 1 & Hutan & 59.849 & 59.409 & 59.237 & 59.141 & 58.875 \\
\hline 2 & Kebun campuran & 5.606 & 5.614 & 5.616 & 5.709 & 5.620 \\
\hline 3 & Ladang/Tegalan & 64.277 & 64.418 & 64.381 & 64.274 & 63.677 \\
\hline 4 & Lahan Terbangun & 3.772 & 4.155 & 4.425 & 4.834 & 6.341 \\
\hline 5 & Lahan Terbuka & 665 & 698 & 740 & 749 & 674 \\
\hline 6 & Sawah & 36.040 & 35.822 & 35.660 & 35.346 & 34.694 \\
\hline 7 & Semak Belukar & 7.518 & 7.610 & 7.667 & 7.674 & 7.846 \\
\hline 8 & Tubuh Air & 2.893 & 2.893 & 2.893 & 2.893 & 2.893 \\
\hline \multicolumn{2}{|c|}{ Jumlah } & 180.614 & 180.614 & 180.614 & 180.614 & 180.614 \\
\hline
\end{tabular}




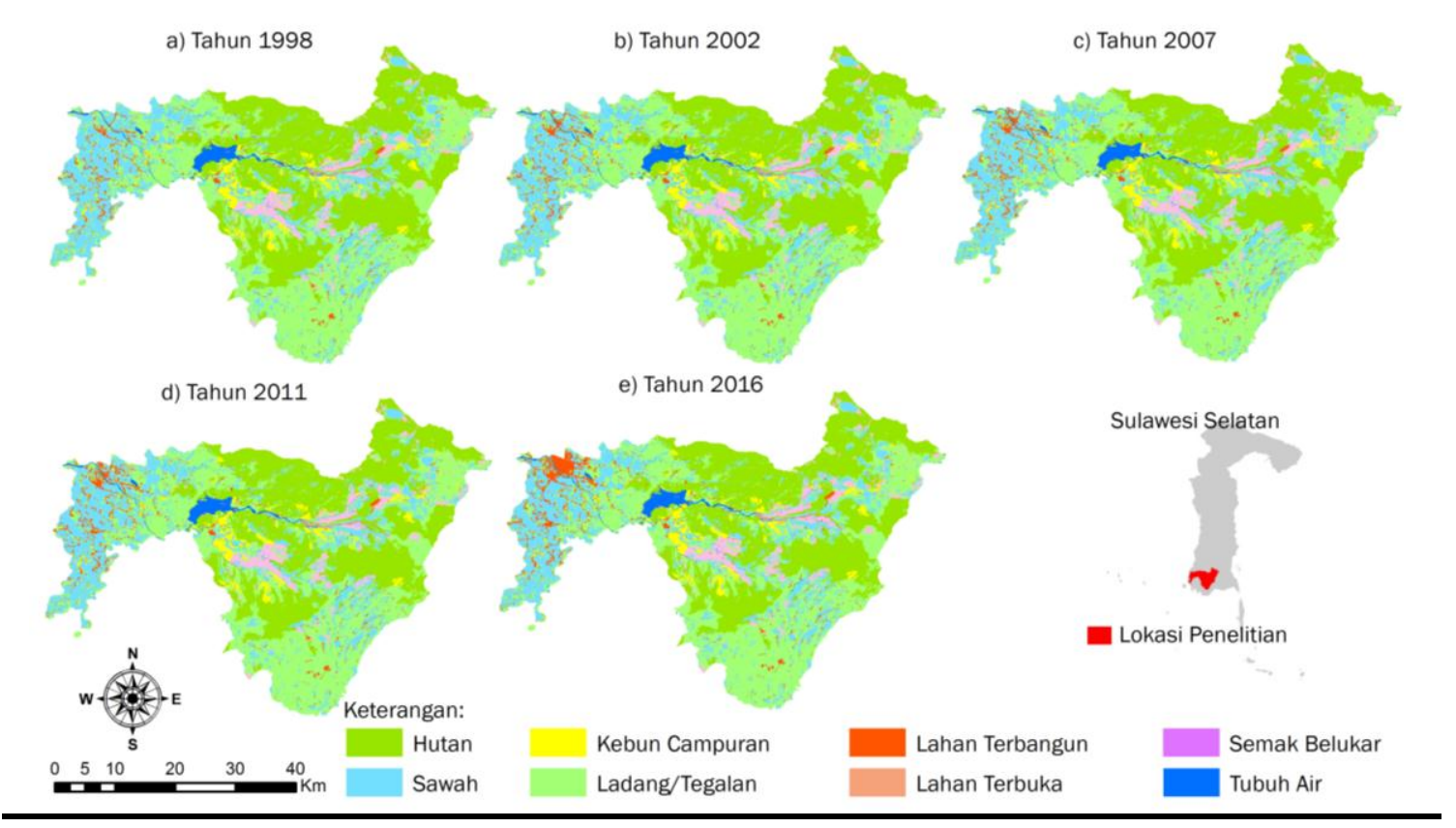

Gambar 3. Peta Penggunaan Lahan di Kabupaten Gowa

Tabel 2. Luas konversi penggunaan lahan Kabupaten Gowa pada berbagai periode pengamatan

\begin{tabular}{|c|c|c|c|c|c|c|c|}
\hline \multirow{3}{*}{ No } & \multirow{3}{*}{$\begin{array}{l}\text { Penggunaan } \\
\text { Lahan }\end{array}$} & \multicolumn{4}{|c|}{ Periode tahun } & \multirow{2}{*}{\multicolumn{2}{|c|}{ Konversi area }} \\
\hline & & \multirow{2}{*}{$\begin{array}{c}\text { 1998-2002 } \\
\text { ha } \\
\end{array}$} & \multirow{2}{*}{$\begin{array}{c}2002-2007 \\
\text { ha }\end{array}$} & \multirow{2}{*}{$\frac{2007-2011}{\mathrm{ha}}$} & \multirow{2}{*}{$\begin{array}{c}2011-2016 \\
\text { ha }\end{array}$} & & \\
\hline & & & & & & ha & $\%$ \\
\hline 1 & Hutan & -440 & -172 & -96 & -266 & -974 & -17 \\
\hline 2 & Kebun campuran & 8 & 3 & 92 & -89 & 14 & 0,2 \\
\hline 3 & Ladang/Tegalan & 141 & -38 & -106 & -598 & -601 & -10 \\
\hline 4 & Lahan Terbangun & 383 & 270 & 409 & 1.507 & 2.569 & 44 \\
\hline 5 & Lahan Terbuka & 33 & 42 & 8 & -75 & 9 & 0,2 \\
\hline 6 & Sawah & -217 & -162 & -314 & -652 & -1.345 & -23 \\
\hline 7 & Semak Belukar & 92 & 57 & 7 & 172 & 328 & 6 \\
\hline 8 & Tubuh Air & 0 & 0 & 0 & 0 & 0 & 0 \\
\hline & Jumlah & & & & & 5.840 & 100 \\
\hline
\end{tabular}

Penambahan luasan (+), Penurunan luasan (-)

Matriks transisi konversi penggunaan lahan di Kabupaten Gowa periode tahun 1998-2016 disajikan pada Tabel 3. Berdasarkan matriks transisi tersebut dapat dilihat bahwa selain tubuh air, penggunaan lahan yg lain telah terkonversi menjadi lahan terbangun. Diantara penggunaan lahan tersebut, sawah merupakan penggunaan lahan yang paling tinggi luas konversinya menjadi lahan terbangun yaitu sebesar 1.298 ha atau $51 \%$, disusul penggunaan lahan ladang/tegalan sebesar 1.029 ha atau $40 \%$, kebun campuran sebesar 93 ha atau 3.6\%, dan semak belukar sebesar 83 ha atau 3.2\%.

Konversi penggunaan lahan sawah dan ladang/tegalan menjadi lahan terbangun di Kabupaten Gowa secara spasial ditemukan terkonsentrasi pada wilayah yang berbatasan langsung dengan Kota Makassar. Jika ditinjau dari karakter spasial konversi tersebut, memperlihatkan bahwa hasil konversi yang terjadi diakhir periode pengamatan pada dasarnya tercipta dari semakin melebarnya proses konversi yang telah berlangsung diawal periode pengamatan. Proses konversi tersebut utamanya berlangsung lebih intens pada periode tahun 2007-2011 dan periode tahun 2011-2016, yaitu setelah meningkatnya status metropolitan Mamminasata menjadi KSN Mamminasata pada tahun 2008, menyebabkan proses pembangunan fisik berjalan lebih akseleratif. Dalam hal ini, penggunaan lahan 
sawah dan ladang/tegalan yang dekat dengan Kota Makassar memiliki peluang konversi yang lebih besar karena lokasinya yang lebih strategis dan relatif mudah diakses, terutama untuk penggunaan yang bersifat komersil.

Tabel 3 . Matriks transisi konversi lahan periode tahun 1998-2016

\begin{tabular}{|c|c|c|c|c|c|c|c|c|c|}
\hline \multirow{3}{*}{$\begin{array}{c}\text { Penggunaan } \\
\text { lahan tahun } \\
1998\end{array}$} & \multicolumn{8}{|c|}{ Penggunaan Lahan tahun 2016} & \multirow[b]{2}{*}{ Jumlah } \\
\hline & Hutan & $\begin{array}{c}\text { Kebun } \\
\text { campuran }\end{array}$ & $\begin{array}{c}\text { Ladang/ } \\
\text { Tegalan } \\
\end{array}$ & $\begin{array}{c}\text { Lahan } \\
\text { Terbangun }\end{array}$ & $\begin{array}{c}\text { Lahan } \\
\text { Terbuka }\end{array}$ & Sawah & $\begin{array}{c}\text { Semak } \\
\text { Belukar }\end{array}$ & $\begin{array}{c}\text { Tubuh } \\
\text { Air }\end{array}$ & \\
\hline & ha & ha & ha & ha & ha & ha & ha & ha & ha \\
\hline Hutan & 58.750 & 80 & 458 & 41 & 5 & - & 390 & - & 59.724 \\
\hline Kebun campuran & - & 5.512 & 2 & 93 & - & - & - & - & 5.607 \\
\hline Ladang/Tegalan & - & 21 & 63.199 & 1.029 & 29 & - & - & - & 64.278 \\
\hline $\begin{array}{l}\text { Lahan } \\
\text { Terbangun }\end{array}$ & - & - & - & 3.772 & - & - & - & - & 3.772 \\
\hline Lahan Terbuka & - & - & - & 25 & 641 & - & - & - & 666 \\
\hline Sawah & - & 8 & 18 & 1.298 & - & 34.694 & 22 & - & 36.040 \\
\hline Semak Belukar & - & - & - & 83 & - & - & 7.435 & - & 7.518 \\
\hline Tubuh Air & - & - & - & - & - & - & - & 2.893 & 2.893 \\
\hline Jumlah & 58.750 & 5.621 & 63.677 & 6.341 & 675 & 34.694 & 7.847 & 2.893 & 180.614 \\
\hline
\end{tabular}
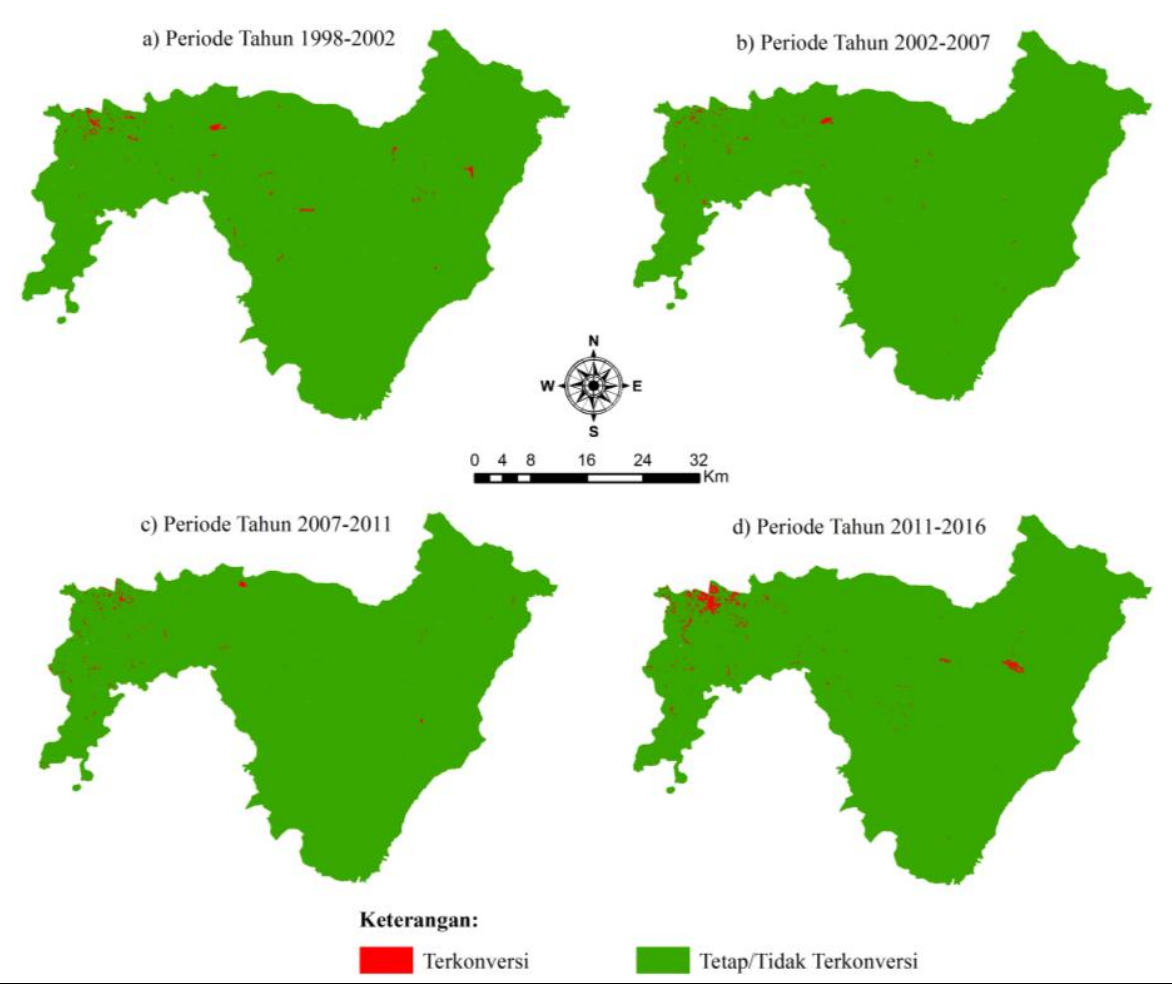

Gambar 4. Tren konversi penggunaan lahan pada berbagai periode tahun pengamatan

\section{Faktor Penentu Konversi Lahan}

Ringkasan hasil analisis regresi logistik biner konversi penggunaan lahan sawah menjadi lahan terbangun disajikan pada Tabel 4. Nilai percentage corret masing-masing faktor sebesar 95.5 yang berarti bahwa model dapat menjawab ketepatan penelitian dengan tingkat kepercayaan sebesar $95 \%$. Nilai signifikansi $<0.05$ yang berarti faktor-faktor 
penentu yang digunakan dapat memberikan pengaruh parsial terhadap kejadian konversi sawah menjadi lahan terbangun. Faktor yang mempengaruhi konversi sawah menjadi lahan terbangun, dikelompokkan atas faktor yang berperan meningkatkan (+) peluang konversi dan menurunkan (-) peluang konversinya.

Faktor penentu kepadatan penduduk berpengaruh meningkatkan peluang konversi penggunaan lahan sawah menjadi lahan terbangun dengan nilai koefisien 1.230, yang berarti semakin padat penduduknya, semakin tinggi peluang konversinya. Hal tersebut diduga karena wilayah dengan kepadatan penduduk yang lebih tinggi, cenderung memiliki aktivitas yang lebih kompleks, dengan tingkat kebutuhan lahan yang lebih besar terutama untuk perumahan, pembangunan infrastruktur, industri, dan jasa. Dwinanto, dkk (2016) mengemukakan bahwa daerah dengan tingkat kepadatan penduduk yang lebih tinggi akan menyebabkan laju konversi lahan sawah yang lebih dominan. Faktor penentu lain yaitu jarak dari pasar dengan nilai koefisien sebesar 0.214. Artinya, semakin dekat penggunaan lahan sawah tersebut dengan pasar semakin rentan untuk terkonversi. Pada dasarnya, keberadaan pasar sebagai pusat aktivitas ekonomi cenderung memiliki daya tarik aglomeratif, sehingga dapat mendorong terciptanya aktivitas-aktivitas ekonomi lain yang membutuhkan ketersediaan ruang wilayah untuk mendukung aktivitasnya.

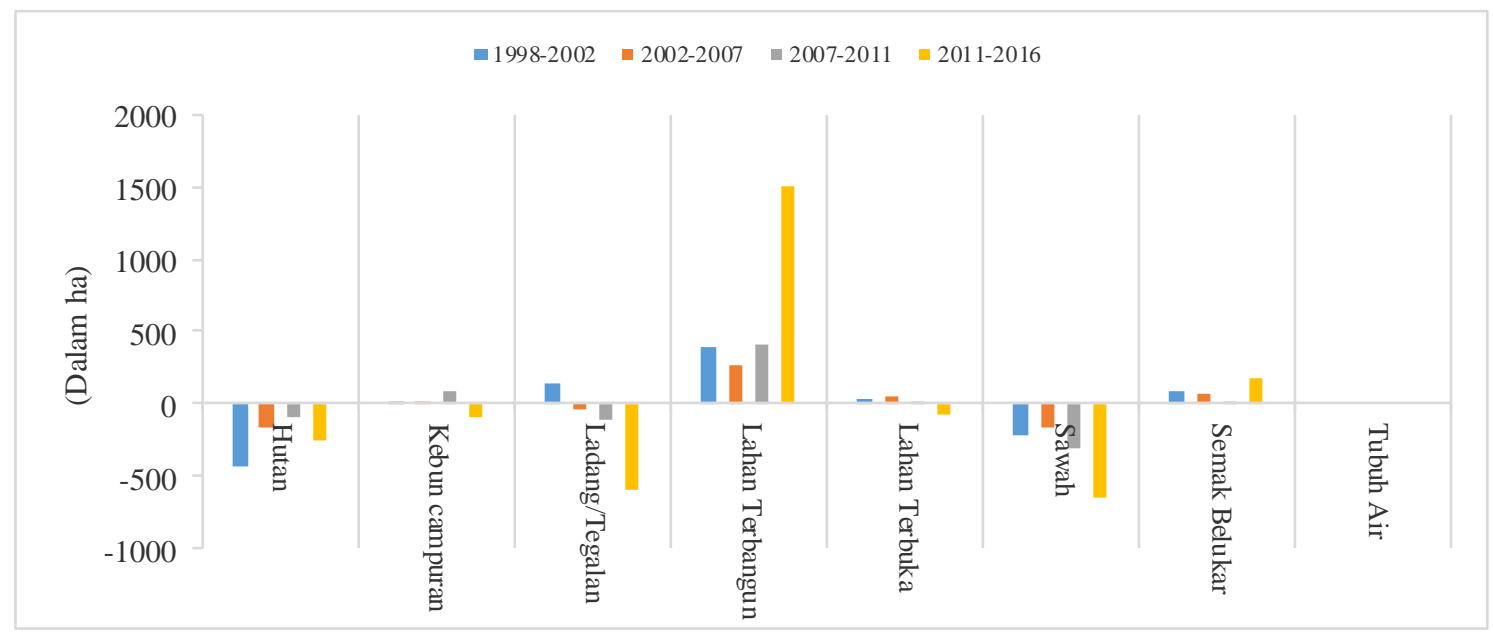

Gambar 5. Grafik tren konversi penggunaan lahan di Kabupaten Gowa tiap-tiap periode pengamatan

Tabel 4. Faktor penentu konversi lahan sawah menjadi lahan terbangun

\begin{tabular}{cllccc}
\hline \multirow{2}{*}{ No } & \multicolumn{1}{c}{ Faktor penentu } & B & $\begin{array}{c}\text { Percentage } \\
\text { Correct }\end{array}$ & Sig. & Exp(B) \\
\hline 1 & Kepadatan penduduk & 1,230 & 95,5 &, 000 & 3,420 \\
2 & Jarak dari kota kabupaten & $-0,707$ & 95,5 &, 000 & 0,493 \\
3 & Jarak dari kota kecamatan & $-0,539$ & 95,5 &, 000 & 0,583 \\
4 & Jarak dari pasar & 0,214 & 95,5 &, 008 & 1,238 \\
5 & Kebijakan pola ruang Kabupaten Gowa & 0,698 & 95,5 &, 000 & 2,010 \\
6 & Integrasi dengan KSN Mamminasata & 1,319 & 95,5 &, 000 & 3,738 \\
\hline & Konstanta & $-9,170$ & &, 000 & 0,000 \\
\hline
\end{tabular}

Faktor lain berupa kebijakan pola ruang Kabupaten Gowa dengan nilai koefisien sebesar 0,698, yaitu pada kawasan yang ditetapkan untuk aktivitas terbangun. Hal tersebut menjelaskan bahwa terjadi hubungan yang kuat antara penetapan kawasan terbangun dalam pola ruang dengan meningkatnya konversi lahan sawah menjadi lahan terbangun. 
Penetapan kawasan terbangun dalam pola ruang Kabupaten Gowa memang mayoritas berada pada penggunaan lahan sawah. Selain itu, wilayah yang terintegrasi dengan KSN Mamminasata juga meningkatkan potensi konversi sawah menjadi lahan terbangun dengan nilai koefisien 1.319, artinya bahwa tekanan konversi lebih besar pada wilayah yang terintegrasi dengan KSN Mamminasata dibandingkan pada wilayah di luar KSN Mamminasata.

Faktor yang berpengaruh signifikan terhadap menurunnya peluang konversi lahan sawah menjadi lahan terbangun adalah jarak dari ibukota Kabupaten dengan nilai koefisien sebesar -0.707, dan jarak dari ibukota kecamatan dengan nilai koefisien -0.539. Hal tersebut diduga karena keberadaan lahan sawah di dekat ibukota kabupaten dan ibukota kecamatan sudah relatif sedikit, kemungkinan karena proses konversi tersebut telah terjadi pada periode sebelumnya. Ringkasan hasil analisis regresi logistik biner faktor penentu penggunaan lahan ladang/tegalan menjadi lahan terbangun disajikan pada Tabel 5. Hasil analisis menunjukkan nilai percentage corret masing-masing faktor sebesar 94.6 yang berarti bahwa model dapat menjawab ketetapatan penelitian dengan tingkat kepercayaan sebesar $94 \%$, signifikansi <0.05. Terdapat tujuh faktor penentu dari 11 faktor yang mempengaruhi konversi penggunaan lahan ladang/tegalan menjadi lahan terbangun, dimana terdapat 5 faktor yang berpengaruh meningkatkan peluang konversi, dan 3 faktor berpengaruh menurunkan peluang konversi tersebut.

Tabel 5. Faktor penentu konversi penggunaan lahan ladang/tegalan menjadi lahan terbangun

\begin{tabular}{|c|c|c|c|c|c|}
\hline No & Faktor penentu & B & $\begin{array}{c}\text { Percentage } \\
\text { Correct }\end{array}$ & Sig. & $\operatorname{Exp}(B)$ \\
\hline 1 & Kemiringan lereng & $-0,376$ & 94,6 & 000 & 0,686 \\
\hline 2 & Kepadatan penduduk & 0,388 & 94,6 &, 000 & 1,474 \\
\hline 3 & Jarak dari jalan arteri & 0,190 & 94,6 & 001 & 1,209 \\
\hline 4 & Jarak dari kota kabupaten & $-0,561$ & 94,6 & 000 & 0,571 \\
\hline 5 & Jarak dari objek wisata & 0,409 & 94,6 & 000 & 1,506 \\
\hline 6 & Kebijakan pola ruang Kabupaten Gowa & 0,522 & 94,6 & 000 & 1,686 \\
\hline \multirow[t]{2}{*}{7} & Integrasi KSN Mamminasata & 0,763 & 94,6 & , 000 & 2,145 \\
\hline & Konstanta & $-4,393$ & & 000 & 0,012 \\
\hline
\end{tabular}

Faktor yang berpengaruh meningkatkan peluang konversi penggunaan lahan ladang/tegalan menjadi lahan terbangun yaitu faktor penentu kepadatan penduduk dengan nilai koefisien 0.388, jarak dari jalan arteri 0,190, jarak dari objek wisata 0,409, kebijakan pola ruang Kabupaten Gowa 0.522, dan Integrasi ke dalam KSN Mamminasata dengan nilai koefisien 0.763. Adapun faktor yang berpengaruh menurunkan peluang konversi penggunaan lahan ladang/tegalan menjadi lahan terbangun meliputi kemiringan lereng dengan nilai koefisien -0.376 , dan jarak dari kota kabupaten dengan nilai koefisien sebesar 0.561. Faktor penentu kepadatan penduduk dalam konteks konversi ladang/tegalan menjadi lahan terbangun juga turut berpengaruh dalam meningkatkan peluang konversinya. Dilain sisi, proses konversi tersebut juga lebih rentan terjadi pada lokasi yang lebih mudah diakses dari jalan arteri. Penetapan kawasan terbangun dalam pola ruang Kabupaten Gowa, serta pengintegrasian ke dalam KSN Mamminasata turut berkontribusi memberi pengaruh dalam meningkatkan peluang konversi penggunaan lahan ladang/tegalan menjadi lahan terbangun.

Faktor penentu kemiringan lereng berpotensi menurunkan peluang konversi penggunaan lahan ladang/tegalan menjadi lahan terbangun. Hal ini karena ladang/tegalan yang terdapat di Kabupaten Gowa banyak memanfaatkan lahan yang agak curam sampai curam dengan komoditi utama berupa ubi kayu, ubi jalar, kentang, dan wortel. Lahan yang berada pada kelerengan agak curam sampai curam secara hitung-hitungan usaha bukan pertanian tidak terlalu efisien karena membutuhkan cost yang besar dan lokasinya yang 
kurang strategis. Selain faktor penentu kemiringan lereng, faktor penentu jarak dari ibukota Kabupaten juga turut berpengaruh menurunkan peluang konversi penggunaan lahan ladang/tegalan menjadi lahan terbangun.

\section{Dinamika Konversi Penggunaan Lahan}

\section{Sekuen Konversi Penggunaan Lahan}

Sekuen konversi penggunaan lahan adalah gambaran pola konversi penggunaan lahan dari waktu ke waktu. Dalam penelitian ini, sekuen konversi penggunaan lahan diperoleh dari ekstraksi nilai atribut peta konversi penggunaan lahan dalam empat periode pengamatan. Gambaran sekuen konversi penggunaan lahan tersebut disajikan dalam sebuah matriks seperti pada Tabel 6. Selama periode tahun 1998-2016, terdapat beberapa area (polygon) dari empat penggunaan lahan yang memperlihatkan sebuah sekuen dalam proses konversinya yaitu penggunaan lahan hutan, kebun campuran, ladang/tegalan, dan sawah. Proses konversi tersebut ada yang terjadi secara langsung pada periode pertama dan ada yang baru mengalami konversi pada periode selanjutnya. Proses konversi yang terjadi pada keempat penggunaan lahan tersebut berakhir menjadi lahan terbangun pada akhir periode pengamatan (Gambar 6).

Tabel 6. Sekeun konversi penggunaan lahan di Kabupaten Gowa

\begin{tabular}{clllll}
\hline \multirow{2}{*}{ No } & \multicolumn{5}{c}{ Penggunaan lahan } \\
\cline { 2 - 5 } & \multicolumn{1}{c}{ Tahun 1998 } & \multicolumn{1}{c}{ Tahun 2002 } & \multicolumn{1}{c}{ Tahun 2007 } & \multicolumn{1}{c}{ Tahun 2011 } & Tahun 2016 \\
\hline 1 & Hutan & Hutan & Lahan Terbuka & Lahan Terbuka & Lahan Terbangun \\
2 & Hutan & Semak Belukar & Semak Belukar & Semak Belukar & Lahan Terbangun \\
3 & Hutan & Ladang/Tegalan & Ladang/Tegalan & Lahan Terbangun & Lahan Terbangun \\
4 & Kebun Campuran & Kebun Campuran & Lahan Terbuka & Lahan Terbuka & Lahan Terbangun \\
5 & Kebun Campuran & Kebun Campuran & Lahan Terbangun & Ladang/Tegalan & Lahan Terbangun \\
6 & Ladang/Tegalan & Ladang/Tegalan & Lahan Terbuka & Lahan Terbuka & Lahan Terbangun \\
7 & Sawah & Sawah & Sawah & Lahan Terbuka & Lahan Terbangun \\
8 & Sawah & Sawah & Sawah & Semak Belukar & Lahan Terbangun \\
9 & Sawah & Kebun Campuran & Kebun Campuran & Kebun Campuran & Lahan Terbangun \\
10 & Sawah & Sawah & Sawah & Ladang/Tegalan & Lahan Terbangun \\
11 & Sawah & Lahan Terbuka & Lahan Terbuka & Lahan Terbuka & Lahan Terbangun \\
\hline
\end{tabular}

\section{Indeks Dinamika Konversi Penggunaan Lahan}

Indeks dinamika konversi penggunaan lahan (Ki) pada periode pengamatan yang berbeda ditunjukkan pada Tabel 7. Interpretasi dari analisis ini dibedakan menjadi penggunaan lahan yang dinamis berkembang (indeks $\mathrm{Ki}>0$ ), dan dinamis menurun (indeks $\mathrm{Ki}<0)$. Hasil analisis menunjukkan bahwa lahan terbangun merupakan penggunaan lahan yang paling dinamis berkembang di Kabupaten Gowa pada keseluruhan periode pengamatan dengan indeks Di sebesar $14.26 \%$, disusul semak belukar sebesar $1.08 \%$, yang menandakan kedua penggunaan lahan tersebut semakin berkembang di wilayah ini dari waktu ke waktu.

Terdapat dua penggunaan lahan yang paling dinamis menurun (indeks $\mathrm{Ki}<0$ ) pada keseluruhan periode pengamatan, meliputi penggunaan lahan sawah dengan indeks $\mathrm{Di}$ sebesar $-0.94 \%$, ladang/tegalan -0.23 dan hutan $-0.4 \%$. Artinya, penggunaan lahan tersebut semakin menurun di wilayah ini dari waktu ke waktu. Adapun penggunaan lahan kebun campuran dan lahan terbuka memiliki indeks Ki relatif rendah, yang menandakan bahwa penggunaan lahan tersebut memiliki tingkat perkembangan atau penururan yang relatif rendah di wilayah ini. 


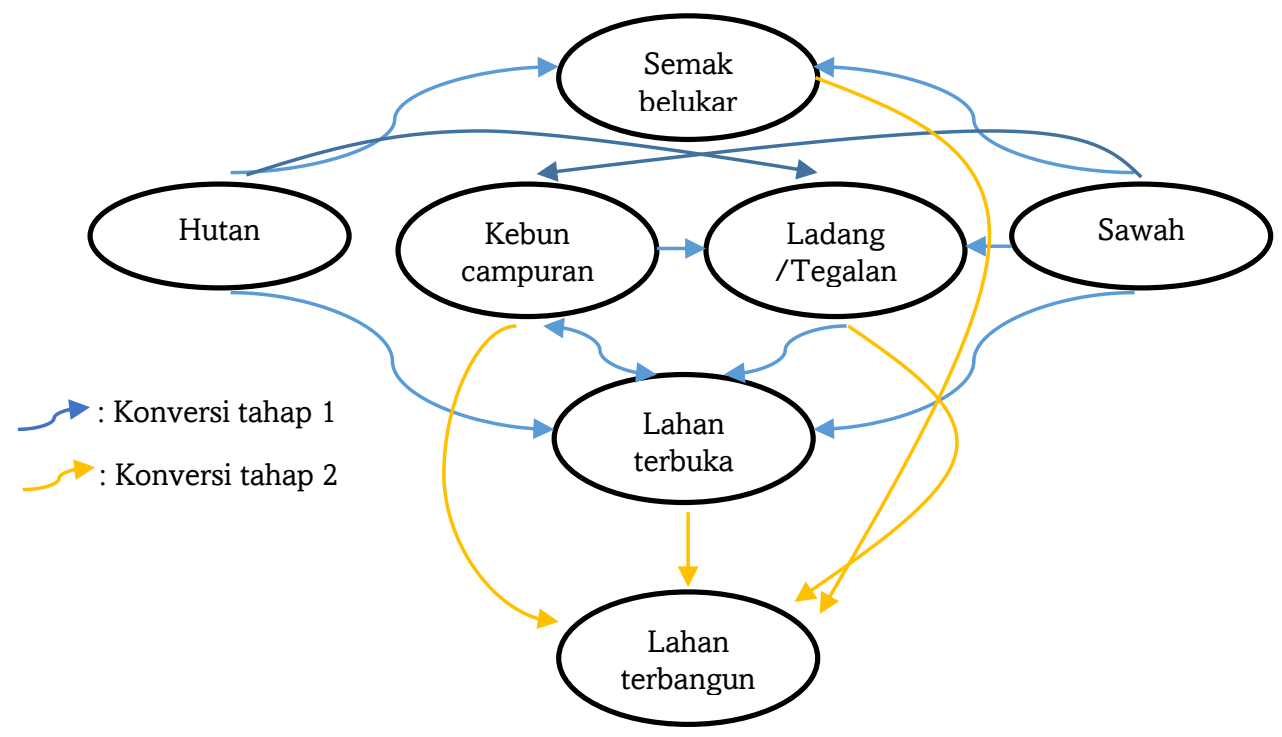

Gambar 6. Sekuen konversi penggunaan lahan di Kabupaten Gowa

Tabel 7. Indeks dinamika konversi penggunaan lahan (Ki) di Kabupaten Gowa

\begin{tabular}{|c|c|c|c|c|c|c|c|c|c|c|}
\hline \multirow[b]{3}{*}{ No } & \multirow{3}{*}{$\begin{array}{l}\text { Penggunaan } \\
\text { Lahan }\end{array}$} & \multicolumn{8}{|c|}{ Periode tahun } & \multirow[b]{3}{*}{$\begin{array}{c}\text { Indeks } \\
\mathrm{Ki}(\%)\end{array}$} \\
\hline & & \multicolumn{2}{|c|}{ 1998-2002 } & \multicolumn{2}{|c|}{$2002-2007$} & \multicolumn{2}{|c|}{$2007-2011$} & \multicolumn{2}{|c|}{ 2011-2016 } & \\
\hline & & $\begin{array}{c}\text { Luas } \\
\text { konversi } \\
\text { (ha) }\end{array}$ & $\begin{array}{l}\text { Indeks } \\
\mathrm{Ki}(\%)\end{array}$ & $\begin{array}{c}\text { Luas } \\
\text { konversi } \\
\text { (ha) }\end{array}$ & $\begin{array}{l}\text { Indeks } \\
\mathrm{Ki}(\%)\end{array}$ & $\begin{array}{c}\text { Luas } \\
\text { konversi } \\
\text { (ha) }\end{array}$ & $\begin{array}{l}\text { Indeks } \\
\mathrm{Ki}(\%)\end{array}$ & $\begin{array}{c}\text { Luas } \\
\text { konversi } \\
\text { (ha) }\end{array}$ & $\begin{array}{l}\text { Indeks } \\
\mathrm{Ki}(\%)\end{array}$ & \\
\hline 1 & Hutan & -440 & $-0,18$ & -172 & $-0,07$ & -96 & $-0,04$ & -266 & $-0,11$ & -0.4 \\
\hline 2 & $\begin{array}{l}\text { Kebun } \\
\text { campuran }\end{array}$ & 8 & 0,03 & 3 & 0,01 & 92 & 0,41 & -89 & $-0,39$ & -0.06 \\
\hline 3 & $\begin{array}{l}\text { Ladang/ } \\
\text { Tegalan }\end{array}$ & 141 & 0,05 & -38 & $-0,01$ & -106 & $-0,04$ & -598 & $-0,23$ & -0.23 \\
\hline 4 & $\begin{array}{l}\text { Lahan } \\
\text { Terbangun }\end{array}$ & 383 & 2,54 & 270 & 1,62 & 409 & 2,31 & 1.507 & 7,79 & 14.26 \\
\hline 5 & $\begin{array}{l}\text { Lahan } \\
\text { Terbuka }\end{array}$ & 33 & 1,24 & 42 & 1,50 & 8 & 0,28 & -75 & $-2,49$ & 0.53 \\
\hline 6 & Sawah & -217 & $-0,15$ & -162 & $-0,11$ & -314 & $-0,22$ & -652 & $-0,46$ & -0.94 \\
\hline 7 & $\begin{array}{l}\text { Semak } \\
\text { Belukar }\end{array}$ & 92 & 0,31 & 57 & 0,19 & 7 & 0,02 & 172 & 0,56 & 1.08 \\
\hline 8 & Tubuh Air & 0 & 0 & 0 & 0 & 0 & 0 & 0 & 0 & 0 \\
\hline
\end{tabular}

\section{Indeks Intensitas Konversi Penggunaan Lahan}

Indeks intensitas konversi penggunaan lahan (Di) pada berbagai tipe transformasi penggunaan lahan disajikan pada Tabel 8. Hasil analisis dikelompokkan ke dalam empat kategori berdasarkan intensitas konversinya, meliputi kategori tinggi dengan nilai indeks Di $>0.20 \%$, kategori sedang dengan nilai indeks $\mathrm{Di}>0.10-<0.20$, kategori rendah dengan nilai indeks $\mathrm{Di}>0.00-<0.10 \%$, dan kategori statis dengan nilai indeks Di $0 \%$.

Tabel 8 menunjukkan bahwa transformasi penggunaan lahan sawah, ladang/tegalan, dan semak belukar menjadi lahan terbangun merupakan tipe transformasi penggunaan lahan yang termasuk ke dalam kategori tinggi (indeks $\mathrm{Di}>20 \%$ ). Hal tersebut menandakan bahwa ada interaksi yang intens antara penggunaan lahan tersebut dengan lahan terbangun. Adapun yang termasuk dalam kategori rendah (indeks $\mathrm{Di}>0.00<0.10$ ), yaitu pada transformasi hutan menjadi lahan terbuka dan semak belukar, serta transformasi sawah menjadi kebun campuran, ladang tegalan, dan lahan terbuka. Distribusi spasial 
indeks intensitas konversi penggunaan lahan (Di) di Kabupaten Gowa disajikan berdasarkan batas administrasi desa seperti pada Gambar 7.

Tabel 8. Indeks intensitas konversi pada berbagai tipe transformasi penggunaan lahan

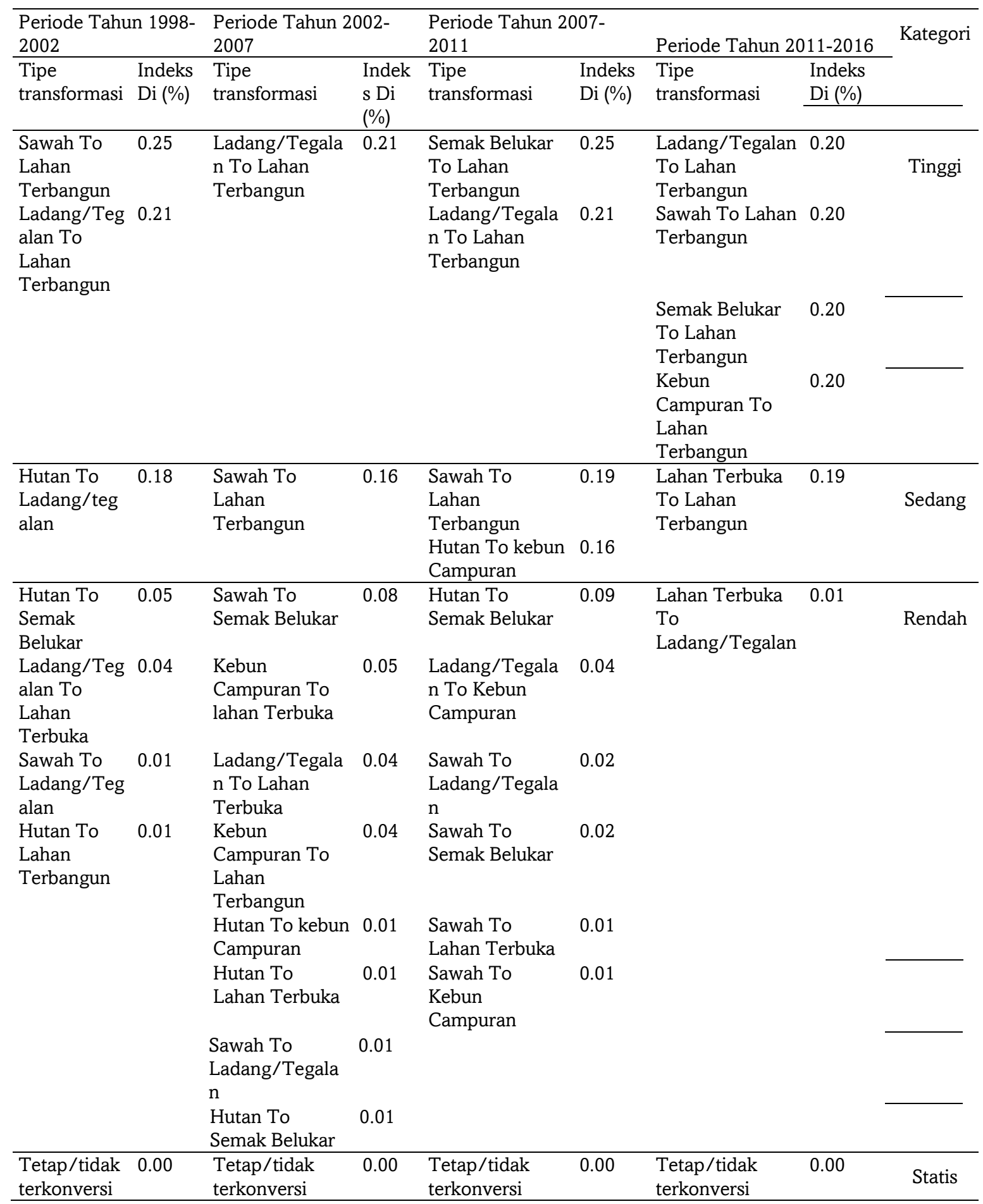




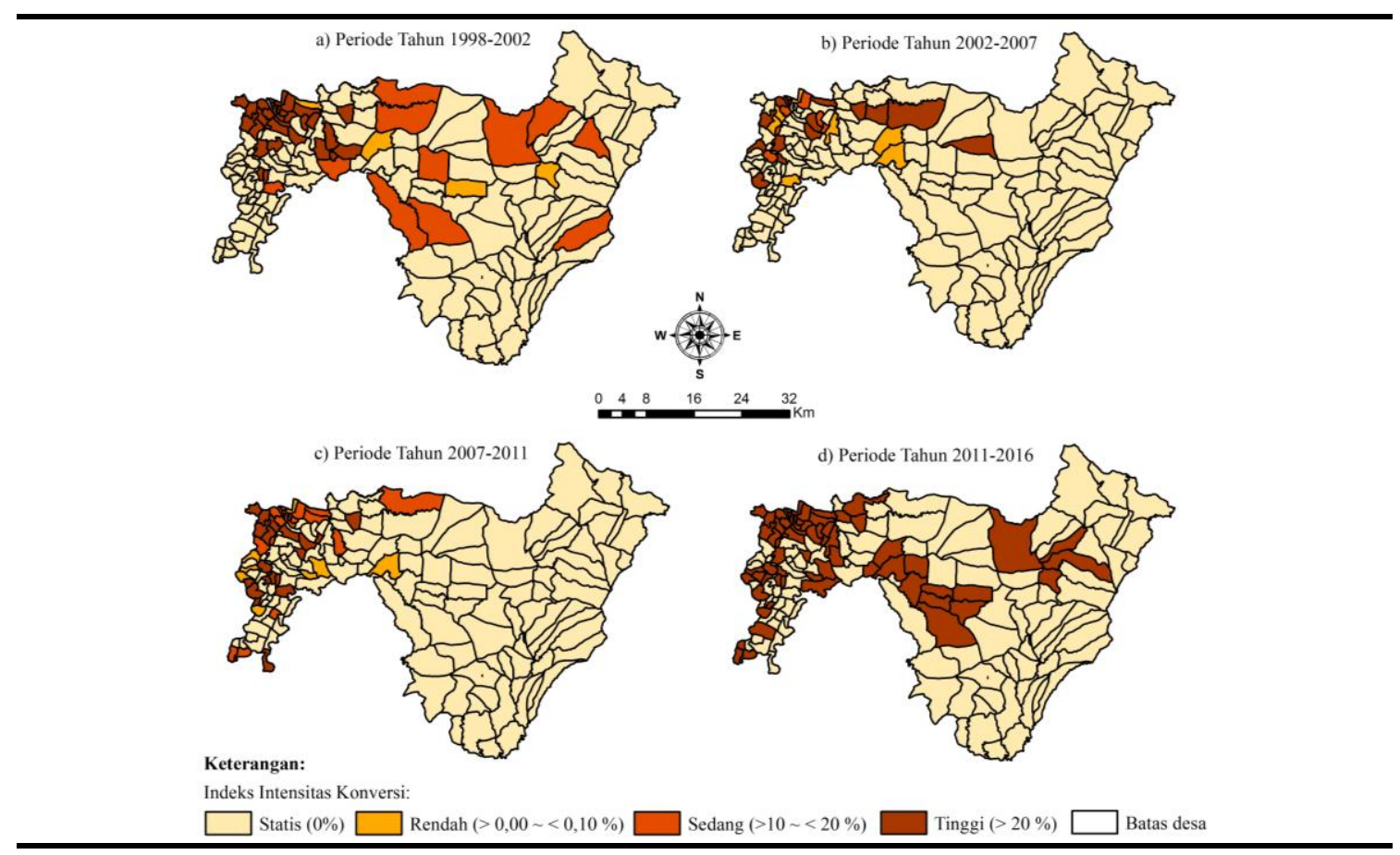

\section{Gambar 7. Distribusi spasial indeks intensitas konversi penggunaan lahan di Kabupaten Gowa}

Indeks intensitas konversi penggunaan lahan (Di) pada berbagai periode pengamatan disajikan pada Tabel 9, yang diperoleh dari total indeks intensitas konversi penggunaan lahan pada berbagai tipe transformasi dalam tiap-tiap periode pengamatan. Hasil analisis menunjukkan bahwa selain periode tahun 2007-2011, periode pengamatan lainnya memiliki indeks intensitas konversi penggunaan lahan $>1$. Hal tersebut mengindikasikan bahwa pada periode tersebut intensitas konversi lahan berlangsung cepat. Adapun pada periode tahun 2002-2007 memiliki nilai indeks intensitas konversi sebesar $0.84 \%$, yang berarti intensitas konversi lahan pada periode tersebut berlangsung lambat.

Tabel 9. Indeks intensitas konversi pada berbagai periode pengamatan di Kabupaten Gowa

\begin{tabular}{clllll}
\hline \multirow{2}{*}{ No } & \multirow{2}{*}{ Periode Tahun } & Jumlah sampel & Indeks Di (\%) & Nilai minumum & \multirow{2}{*}{ Nilai maksimum } \\
\hline 1 & $1998-2002$ & 11 & 1.00 & 0.00 & 0.25 \\
2 & $2002-2007$ & 11 & 0.84 & 0.00 & 0.21 \\
3 & $2007-2011$ & 11 & 1.25 & 0.00 & 0.25 \\
4 & $2011-2016$ & 8 & 1.20 & 0.00 & 0.20 \\
\hline
\end{tabular}

\section{KESIMPULAN}

Berdasarkan hasil penelitian dapat disimpulkan bahwa selama periode tahun 19982016 telah terjadi konversi lahan di Kabupaten Gowa sebesar 5.840 ha $(3.23 \%)$. Penggunaan lahan yang mengalami peningkatan luasan meliputi kebun campuran, lahan terbangun, lahan terbuka, dan semak belukar yang menyebabkan terjadinya penurunan luasan pada penggunaan lahan sawah, ladang/tegalan dan hutan. Selain penggunaan lahan tubuh air, penggunaan lahan yg lain telah terkonversi menjadi lahan terbangun dengan luas konversi yang tertinggi yaitu pada penggunaan lahan (51\%), dan penggunaan lahan ladang/tegalan (40\%). Faktor penentu yang signifikan mempengaruhi konversi penggunaan lahan sawah menjadi lahan terbangun meliputi kepadatan penduduk, jarak dari ibukota kabupaten, jarak dari ibukota kecamatan, jarak dari pasar, kebijakan pola ruang Kabupaten Gowa, dan Integrasi ke dalam KSN Mamminasata. Adapun konversi dari 
ladang/tegalan menjadi lahan terbangun dipengaruhi oleh faktor penentu kemiringan lereng, kepadatan penduduk, jarak dari jalan arteri, jarak dari kota kabupaten, jarak dari objek wisata, kebijakan pola ruang Kabupaten Gowa, dan Integrasi ke dalam KSN Mamminasata.

Penggunaan lahan paling dinamis berkembang yaitu lahan terbangun dan semak belukar, sementara penggunaan lahan yang paling dinamis menurun meliputi penggunaan lahan sawah, ladang/tegalan, dan hutan. Intensitas konversi lahan tertinggi yaitu pada transformasi penggunaan lahan sawah, ladang/tegalan, dan semak belukar menjadi lahan terbangun, yang menandakan bahwa ada interaksi yang intens antara penggunaan lahan tersebut dengan lahan terbangun, sedangkan yang terendah yaitu pada transformasi hutan menjadi lahan terbuka dan semak belukar, serta transformasi sawah menjadi kebun campuran, ladang tegalan, dan lahan terbuka. Tingkat intensitas konversi lahan yang berlangsung cepat terjadi terjadi pada periode tahun 1998-2002, 2007-2011, dan periode tahun 2011-2016.

\section{DAFTAR PUSTAKA}

Ashari A.F. 2015. Analisis Perubahan Penggunaan Lahan Dengan Aplikasi Model Clue-S Untuk Arahan Pemanfaatan Ruang Di Kawasan Strategis Nasional Mamminasata, Sulawesi Selatan [tesis]. Bogor (ID): Institut Pertanian Bogor.

Barus B, Panuju D.R, Iman L.S, Trisasongko B.H, Gandasasmita K, Kusumo R. 2012. Pemetaan Potensi Konversi Lahan Sawah Dalam Kaitan Lahan Pertanian Berkelanjutan Dengan Analisis Spasial. Bogor (ID): Departemen Ilmu Tanah dan Sumber Daya Lahan IPB dan Pusat Pengkajian Perencanaan dan Pengembangan Wilayah IPB.

Dwinanto A.A.P, Munibah K, Sudadi U. 2016. Model Perubahan Dan Arahan Penggunaan Lahan Untuk Mendukung Ketersediaan Beras Di Kabupaten Brebes Dan Kabupaten Cilacap. Jurnal Tata Loka.18(3):157-171.

Fitzmaurice G.M, Laird N.M. 2015. Binary Response Models And Logistic Regression. Harvard School of Public Health, Harvard University, Boston. USA Amerika Serikat (US): Elsevier.

$\mathrm{Gu} \mathrm{W,} \mathrm{Guo} \mathrm{J,} \mathrm{Fan} \mathrm{K,} \mathrm{Edwin} \mathrm{H.W,} \mathrm{Chan.} \mathrm{2016.} \mathrm{Dynamic} \mathrm{Land} \mathrm{Use} \mathrm{Change} \mathrm{And} \mathrm{Sustainable} \mathrm{Urban}$ Development In A Third-Tier City Within Yangtze Delta. International Conference on Geographies of Health and Living in Cities: Making Cities Healthy for All, Healthy Cities. Procedia Environmental Sciences.36(2016):98-105.

Kitchin B, Thrift N. 2009. International Encyclopedia Of Human Geography. Amsterdam (NL): Elsevier.

Liang Y, Xu Z, Fanglei Z. 2011. Land Use Scenario Analysis By Based On System Dynamic Model And CLUE-S Model At Regional Scale: A Case Study Of Ganzhou District Of Zhangye City. Geographical Research.30(3):564-576.

Lillesand T.M, Kiefer R.W. 1997. Penginderaan Jauh dan Interpretasi Citra. Yogyakarta (ID): Gadjah Mada University Press.

Liu M, Hu Y, Zhang W, Zhu J, Chen H, Xi F. 2011. Application Of Land Use Change Model In Guiding Regional Planning: A Case Study In Hun River Watershed, Northeast China. China Geographical Science.21(5):609-618.

Luo Y, Yang S, Liu X. 2014. Land Use Change In The Reach From Hekouzhen To Tongguan Of The Yellow River During 1998-2010. Acta Geographica Sinica.69(1):42-53.

Moghadam H.S, Helbich M. 2013. Spatiotemporal Urbanization Processes In The Megacity Of Mumbai, India: A Markov Chains-Cellular Automata Urban Growth Model. Applied Geographic.40(2013):140-149.

Peng J, Zhao M, Guo X, Pan Y, Liu Y. 2017. Spatial-Temporal Dynamics And Associated Driving Forces Of Urban Ecological Land: A Case Study In Shenzhen City, China. Habitat international. 60 (2017):81-90

Sun P, Xu Y, Yu Z, Liu Q, XIE P, Liu J. 2016. Scenario Simulation And Landscape Pattern Dynamic Changes Of Land Use In The Poverty Belt Around Beijing And Tianjin: A Case Study Of Zhangjiakou City, Hebei Province. Journal of Geographical Sciences.26(3):272-296.

Radhinal Y, Ariyanto. 2017. Koeksistensi Dualisme Ekonomi Di Kawasan Metropolitan Mamminasata. Jurnal Plano Madani.6 (1):97-107.

Surya B. 2015. The Dynamics Of Spatial Structure And Spatial Pattern Changes At The Fringe Area Of Makassar City. Indonesian Journal of Geography.47(1):11-19. 
Thomas R.J, Peethamparan S. 2017. Stepwise Regression Modeling For Compressive Strength Of AlkaliActivated Concrete. Construction and Building Materials. 141(2017):315-324.

Veldkamp A, Lambin E.F, 2001. Predicting Land-Use Change. Agriculture, Ecosystems And Environment.85(1):1-6.

Verburg P.H, Soepboer W, Veldkamp A, Limpiada R, Espaldon V, Mastura S.S.A. 2002. Modeling The Spatial Dynamics Of Regional Land Use: The CLUE-S Model. Environmental Management.30(3):391-405.

Wang S.Y, Liu J.S, Ma T.B, 2010. Dynamics And Changes In Spatial Patterns Of Land Use In Yellow River Basin, China. Land Use Policy.27(2):313-323

Wang X.L, Bao Y.H. 1999. Study On The Methods Of Land Use Dynamic Change Research. Progress in Geography.18(1):81-87.

Warlina L. 2011. Pemodelan Perubahan Guna Lahan (Kasus Kabupaten Majalengka). Jurnal Tata Loka.13(4):235-247.

Zhang L, Yang G, Liu J. 2014. The Dynamic Changes And Hotspots Of Land Use In Fushun City From 1986 To 2012. Scientia Geographica Sinica.34(2):185-191. 